\title{
General Notes
}

\author{
THE WHIPPS CROSS
}

\author{
F.R.C.S. (E.N.T.) COURSE \\ 10-19 February 1986 \\ (Non-Resident)
}

Intensive programme to include tutorials by distinguished invited Otolaryngologists, controversial issues, mock clinical examinations and vivas, with emphasis on clinical examination techniques. Candidates must possess Part I and numbers will be restricted to 20 .

Course Supervisor: Nicholas Frootko M.Sc., F.R.C.S.

Course approved for Study Leave under Section HM(67)27.

Fees: $£ 240$.

Closing date for applications: 27 December, 1985.

Application forms and accommodation information available from:

The Administrator,

Medical Education Centre,

Whipps Cross Hospital,

London E11 1NR

\section{TEMPORAL BONE SURGICAL DISSECTION COURSE OFFERED BY}

THE DEPARTMENT OF OTORHINOLARYNGOLOGY

The University of Michigan Medical School, Ann Arbor, Michigan

Course Co-directors: Malcolm D. Graham, M.D. \& John L. Keminck, M.D.
14-18 April 1986
6-10 October 1986
12-16 May 1986
3-7 November 1986

Intensive one-week courses emphasize the surgical and anatomical approaches to the temporal bone, and are presented in a manner relevant for the otologic surgeon, utilizing lectures, videotapes, and dissection.

Mornings and afternoons are spent in the dissection laboratory, giving extensive drilling experience in temporal bone anatomy and surgical techniques. All instruments and high-speed handpieces will be provided.

Course fee is $\$ 1.000 .00$.

For further information write: Malcolm D. Graham, M.D.,

Department of Otorhinology,

University of Michigan,

Ann Arbor,

Michigan 48109, U.S.A.

Tel: (313) 763-5097 


\section{HEAD AND NECK FOUNDATION}

The Head and Neck Foundation is now running a series of long weekend courses which consider one aspect of head and neck surgery at a time. The last course on Salivary Diseases was held in Edinburgh in May 1985, and the next one on Diseases of the Larynx, both benign and malignant, is to be held in Liverpool in April 1986. The resident faculty are Professor Harrison, Dr. Maran and Professor Stell, and in addition there will be other invited speakers.

The course will be held in the Holiday Inn in Liverpool on 25, 26 and 27 April, 1986.

Course fee is $£ 160$.

Further details and application forms may be obtained from the undersigned:

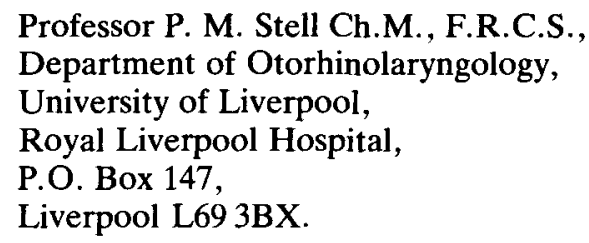

\section{THE SEVENTH BRITISH ACADEMIC CONFERENCE IN OTOLARYNGOLOGY} at the UNIVERSITY OF GLASGOW, SCOTLAND, UNITED KINGDOM

\section{6-31 July 1987}

Leading International experts will discuss recent developments in lectures and panel discussions. Topics to be discussed include:

1. Otology-Cochlear implants, middle ear surgery and reconstruction.

2. Facial plastic and Reconstructive surgery-Myocutaneous and free flaps in Head and Neck surgery.

3. Laryngology-paediatric laryngology, Laser surgery, Laryngology quiz.

4. Nasal Airway disease and surgery.

5. Audiology/Otology quiz.

6. Immunology in otolaryngology. Recent advances in Otolaryngology.

7. Research Forum. Current techniques. Instructional sessions in small seminar groups will cover all aspects of otolaryngology.

Daily audiovisual programme.

Scientific and Trade Exhibitions.

A full social programme arranged.

Registration fee - Members: $£ 300$.

Those interested should apply to:
Air Commodore M. E. Moran, M.Ch., R.A.F.,
Princess Alexandra Hospital Wroughton,
Royal Air Force Wroughton,
Swindon, Wilts. SN4 0QJ, 
UNIVERSITY OF ZURICH, SWITZERLAND

MICROSURGERY OF THE EAR

25-27 September, 1986

Guest: Professor T. Palva, Helsinki

This course entails video (live) demonstrations and in-depth discussions of the various microsurgical techniques used at the University of Zurich and the University of Helsinki ENT Departments.

Fee:

SFr 600.

Information: Professor U. Fisch, ENT Department, University Hospital, 8091 Zurich, Switzerland.

THE TWJ FOUNDATION

THE TRUSTEES OF THE TWJ FOUNDATION INVITE APPLICATIONS

for AN OTOLOGICAL CLINICAL AND RESEARCH FELLOWSHIP tenable at

THE DEPARTMENT OF OTOLARYNGOLOGY, ANN ARBOR

in

THE UNIVERSITY OF MICHIGAN

for

SIX MONTHS COMMENCING APRIL 1986

Professor Malcolm Graham will act as Clinical Tutor to the Fellow and the emphasis will be on neuro-otology and skull bone surgery. The Fellow will also participate in a research project in the Kresge Laboratory under the direction of Dr. Merle Lawrence.

Applicants must be Fellows of one of the Royal Colleges of Surgeons and a Senior Registrar in Otolaryngology in an appointment recognised for Higher Surgical Training.

Further details concerning applications should be obtained now from:

The Trustees of the TWJ Foundation, Courtlands, 61 Kingswood Firs,

Grayshott, Hindhead,

Surrey GU26 6ER

The closing date for formal applications will be:

Saturday, 11 January 1986 


\title{
THE OTOLARYNGOLOGICAL SOCIETY OF AUSTRALIA
}

\section{$34^{\mathrm{TH}}$ ANNUAL GENERAL AND SCIENTIFIC MEETING}

\author{
20-25 April, 1986
}

This meeting will be held at the Inter-Continental Hotel, Sydney, NSW, Australia.

Invited speakers: Prof. Wilfred S. Goodman of Toronto, Canada (Open Rhinoplasty) and

Prof. Herbert H. Dedo of San Francisco, California, U.S.A. (Laryngology).

Contact:

\author{
Dr. R. L. Carroll, \\ $\%$ O.L.S.A., \\ 33-35 Atchison Street, \\ St. Leonards, NSW, 2065, \\ Australia.
}

Telephone: (02)43-5141.

\section{INTERNATIONAL COURSE ON EAR SURGERY, NASAL AND SINUS SURGERY}

(Selva di Valgardena, Dolomiti, Italy - January 11 to 18,1986 )

\section{Course Directors: Gregorio Babighian, M.D. \\ Giorgio Sulsenti, M.D.}

The prime object of this one-week course is to provide the audience with the most updated information about major and controversial topics on ear surgery, cosmetic and functional surgery of the nose and septum, and sinus microsurgery.

The scientific programme (conferences, panels \& quiz, videotapes, etc.) will run in the afternoon, the mornings being at leisure to allow the participants to enjoy the wonderful ski facilities and natural beauties of this famous winter sport area.

The international Faculty includes: Babighian (Italy), Bosch (Spain), Clement (Belgium), De La Cruz (U.S.A.), Marquet (Belgium), Sulsenti (Italy), Sultan (France), Veldman (The Netherlands), Walter (West Germany) and Zini (Italy). Main Topics are: Tympanoplasty and Stapedectomy, Malformations, Facial Nerve Surgery, Eustachian Tube surgery, Homotransplants and Bioimplants, Surgical Reconstruction of the Auricle, Cochlear Implants; as well as Cosmetic and Functional Surgery of the Nose and Septum, Sinus Microsurgery, Vidian Nerve Surgery, Rhinomanometry, Allergy, Secondary Rhinoplasties, Surgery of the Lacrimal Duct.

The official languages are Italian and English, with simultaneous translation.

A very attractive social programme for participants and accompanying persons includes the "Otoski Competition Trophy".

Registration fees before November 15,1985 are US $\$ 270$ for Otolaryngologists and US $\$ 170$ for Residents; for later Registrations add US\$60.

For further information and detailed programme:

M. Amadori, M.D.,

Department of Otolaryngology

Ospedale S. Chiara - 38100 Trento, Italy. 
THE EUROPEAN $\mathrm{CO}_{2}$-LASER WORKSHOP IN E.N.T. SURGERY

\author{
4-6 December, 1985
}

Course Directors: Jørgen W. Paulsen, M.D.

Head of Department of Otorhinolaryngology,

County Hospital, Roskilde.

Palle B. Iversen, M.D.

Department of Otorhinolaryngology,

County Hospital, Roskilde.

Guest Faculty: $\quad$ Robert H. Ossoff, D.M.D., M.D.

Director of Laser Research and Assistant Professor,

Department of Otolaryngology and Maxillofacial Surgery,

Northwestern University Medical School,

Chicago, U.S.A.

Poul Bretlau, M.D., Ph.D.

Professor,

Department of Otolaryngology,

University Hospital,

Copenhagen

A two and a half day Tutorial and Hands on Workshop on the applications on the $\mathrm{CO}_{2}-$ Laser in Otolaryngology-Head and Neck Surgery.

For further information:

J. W. Paulsen, M.D.,

Department of Otolaryngology,

County Hospital,

4000 Roskilde,

Denmark

Phone: (2) 370237 Ext. 451.

METROPOLITAN EAR, NOSE AND THROAT HOSPITAL

JAMES YEARSLEY LECTURE

The James Yearsley Lecture for 1986 will be given at the Royal Society of Medicine, 1 Wimpole Street, London W1, on Friday 7 March, 1986 at 5.00 p.m. when Mr David Brain will speak on 'Famous ENT Surgeons of the Past'. 


\section{INSTRUCTIONAL COURSE ON TINNITUS AND ITS MANAGEMENT}

$$
\text { 7-9 April, } 1986
$$

In association with the Nottingham School of Audiology, the fifth two-and-a-half day course of lectures with discussions, video films and practical sessions will be held on the causes, scientific background, investigation and management of tinnitus.

The course fee (including accommodation for 3 nights, lunches and a course dinner) will be $£ 160$.

Numbers will be strictly limited to a maximum of 40 .

The course is suitable for otologists, audiological physicians, scientists and technicians, and hearing therapists.

It is preferable that, when the course is attended by a consultant, he/she be accompanied by an audiological staff member from the same hospital.

Further enquiries and place reservations in writing to:

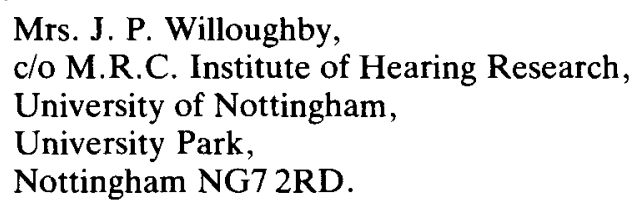

Telephone enquiries to:

Mrs. Willoughby on (0602) 259507.

4th INTERNATIONAL COURSE IN FUNCTIONAL CORRECTIVE NASAL SURGERY

21-26 April, 1986, Utrecht, The Netherlands

This course will be given under the direction of Prof. E. H. Huizing in co-operation with Prof. W. Pirsig (Ulm), Prof. R. Th. R. Wentges (Nijmegen), Prof. S. Hellmich (Dortmund) and E. B. Kern, M.D. (Rochester, U.S.A.).

For information:

Professor Dr. E. H. Huizing,

Department of Otorhinolaryngology,

University Hospital Utrecht,

P.O. Box 16250 ,

Utrecht,

The Netherlands.

Phone: $30-373024$ 